22. Рівіс Й. Ф., Федорук Р. С. Кількісні хроматографічні методи визначення ліпідів і жирних кислот у біологічному матеріалі: метод. пос. Львів: СПОЛОМ, 2010. 109 с.

23. Glanz S. Medico-biological statistics. Moscow: Practice, 1999. 460 p.

24. Байдалинова Л. С., Яржомбек А. А. Биохимия сырья водного происхождения: учеб. пос. М.: МОРКНИГА, 2011. 504 с.

25. Цап М. М., Рівіс Й. Ф. Обмін жирних кислот в організмі коропів за згодовування жирових добавок // Вісник аграрної науки. 2010. № 5. С. 41-44.

Сулейманова Роза Рамісівна, аспірант, кафедра біохімії і фізіології тварин імені академіка М. Ф. Гулого, Національний університет біоресурсів і природокористування України, вул. Героїв Оборони, 15, м. Київ, Україна, 03041

E-mail: 1992_s_roza@ukr.net

Мельничук Дмитро Олексійович, доктор біологічних наук, професор, академік НАН та НААН України, Радник Президії Національної академії наук України, Президія Національної академії наук України, вул. Володимирська, 54, Київ, Україна, 01601

E-mail: d.melnychuk43@gmail.com

Калачнюк Лілія Григорівна, доктор біологічних наук, професор, кафедра біохімії і фізіології тварин імені академіка М. Ф. Гулого, Національний університет біоресурсів і природокористування України, вул. Героїв Оборони, 15, м. Київ, Україна, 03041

E-mail: kalachnyuk_liliya@nubip.edu.ua

УДК 574.2:579.842.11:579.842.14:579.842.22

DOI: 10.15587/2519-8025.2018.141414

\title{
THE RESEARCH OF LITTER IN POULTRY HOUSE AND USE OF ESSENTIAL OILS IN BROILER PRODUCTION
}

\author{
(C) O. Tertychna, L. Svaliavchuk, O. Mineralov
}

Проведено аналіз літературних джерел щуодо актуальності вивчення та лабораторного дослідження підстилкових матеріалів у сучасному птахівництві. Виявлено, що підстилка є не тільки накопичувачем забруднюючих речовин, поживним середовищем для існування патогенних та умовно-патогенних мікроорганізмів, але й може здійснювати збільшення емісії шкідливих газів, таких як аміак, вуглекислий газ та сірководень у разі порушення технології вирощування птиці. Таким чином завдаючи негативного впливу як птиці так і обслуговуючому персоналу птахопідприємств. Дослідженнями підтверджено ефективність використання емульсій ефірних олій проти патогенних та умовно-патогенних мікроорганізмів присутніх у підстилкових матеріалах бройлерного виробництва. Цей метод в майбутньому надасть змогу відмовитися від шкідливих для довкілля хімічних засобів обробки відходів птахівництва.

Мета. Здійснити хімічний та мікробіологічний аналіз підстилки та дослідити бактерицидні властивості ефірних олій.

Матеріали та методи. Дослідження проводились на підприємствах бройлерного виробництва Київської області. Хімічний склад та мікробіологічні дослідження підстилки проводились в«Украӥнській лабораторії якості $і$ безпеки продукиії АПК» та мікробіологічній лабораторії департаменту екології ТОВ «Комплекс Агромарс» відповідно до ДСТУ ISO 11885:2005 та ДСТУ 30726-2002. Дослідження бактериичдних властивостей ефірних олій проводились згідно ДСТУ 50474-93.

Результати досліджень. На початковому етапі вирощування птиці за допомогою лабораторних досліджень було виявлено, щзо у досліджуваних зразках підстилки вологість складала 22,1%, а кількість сухої речовини - 77,9 \%. На завериальному етапі виромування птиці в результаті мікробіологічного дослідження тільки у одному зразку є присутність лактозопозитивних кишкових паличок в 1 г підстилки менше 3, щзо свідчить про ї̈ належний санітарний стан. У всіх зразках досліджуваної підстилки відсутній патогенний мікроорганізм роду Salmonella. Досліджено бактерищидну дію 9 емульсій ефірних олій у конизентрації 0,5 та $1 \%$ проти мікроорганізмів E. coli ma P. vulgaris.

Висновки.У результаті хімічного аналізу підстилки показано наявність не тільки хімічних елементів, домішків (тирси деревини та негашеного вапна), але і присутність органічної речовини у вигляді сирого жиру, сирої клітковини, безазотистих екстрактивних речовин та амінокислот з різним відсотковим складом.

Показано, щчо в зразках підстилки бройлерного виробництва птиці відсутній патогенний мікроорганізм роду Salmonella, це свідчить про високу якість продукиї та задовільний епідеміологічний та санітарний стан досліджуваного птахопідприємства. 
Виявлено бактерицидні властивості 7 з 9 досліджуваних емульсій ефірних олій, в якості антибактеріальних препаратів широкого спектру дї з концентрацією розчину 0,5 та $1 \%$

Ключові слова: підстилка, бройлерне виробництво, патогенні та умовно-патогенні мікроорганізми, ефірні оліі

\section{Introduction}

Modern production of poultry products provides the population with a high quality dietary product. However, the intensification and expansion of poultry production and increase of the size of poultry enterprises leads to harmful ecological effects [1].

According to $[2,3]$, the main problem that will concern livestock in future - is this ecological situation environment. The dynamic development of poultry has a negative impact on the environment, due to poor utilization of by-products of poultry farming, litter, emissions of significant volumes of exhalates, dust, development of insect pest groups, unpleasant smell near poultry enterprises, etc. In addition, the intensive production of poultry products causes greenhouse gas emissions into the atmosphere, soil contamination and eutrophication of water bodies [4].

The impact of poultry farming on the state of the environment depends on a number of factors, including: size of the farm, production system, composition of the diet of the poultry, type of litter, etc. It is known that proper management of poultry wastes, especially poultry litter, can be a valuable resource, that is, it can be used as a fertilizer, soil feeder or as a source of energy [5]. Without proper treatment of poultry litter is an accumulator not only of pollutants, but also pathogenic or conditionally pathogenic microorganisms, which can get into the environment.

The search for environmentally safe ways of disinfection of poultry waste is a promising scientific direction. The research confirms the efficiency of the use of plant extracts that is in the future it will be possible to refuse chemical means of processing of poultry waste harmful to the environment [6].

In addition, essential oils of medicinal plants have immunocorrective properties, which helps to reduce the morbidity and increase the preservation and productivity of the poultry.

\section{Literature review}

Almost all poultry population with egg production technology is grown in battery cages and poultry used for meat production (parent poultry, repair young animals, ducks, geese, turkeys, as well as young poultry grown for meat) - mainly on the floor, on deep litter. Therefore, due to the rapid growth of poultry meat production, especially broiler meat, in recent years, the industry has an increasing demand and deficit of litter materials [7].

It is common knowledge that in the litter under the optimal conditions of the microclimate of the poultry house can develop such pathogenic microorganisms as Salmonella, Campylobacter, Coliform, Proteus, fungi of the genus Aspergillus, etc. Increased temperature and humidity, a sufficient amount of nutrients contribute to the rapid growth and development of microorganisms. It is strictly forbidden to use mold, frozen, wet and not checked by the laboratory for the presence of aspergillosis spores in litter. The humidity of the litter materials should be no more than $20 \%$ according to the technology of poultry breeding $[8,9]$.

In addition to the accumulation of harmful metabolites and microorganisms, the litter has the ability to emit significant amounts of harmful gases - ammonia $\left(\mathrm{NH}_{3}\right)$, carbon dioxide $\left(\mathrm{CO}_{2}\right)$ and hydrogen sulfide $\left(\mathrm{H}_{2} \mathrm{~S}\right)$. According with the technological standards of designing poultry enterprises, the allocation of $\mathrm{NH}_{3}$ with $1 \mathrm{~m}^{2}$ of litter are an average of $25 \mathrm{mg} / \mathrm{h}, \mathrm{CO}_{2}-8 \mathrm{mg} / \mathrm{h}, \mathrm{H}_{2} \mathrm{~S}-$ $15 \mathrm{mg} / \mathrm{h}$ [10]. For non-compliance with growing technologies, emissions of harmful gases can be increased several times and, accordingly, high $\mathrm{NH}_{3}$ content in poultry air has a negative impact on the keeping and productivity of poultry, the health of the staff, and the ventilation emissions of poultry houses on the environment $[11,12]$.

Research by many scientists found that one of the important factors that negatively affects the ecology of industrial poultry, is a huge accumulation of microflora in the air, equipment and litter materials of poultry houses [13].

Under favorable microclimate conditions in poultry facilities, the number of microorganisms and their composition is such that between them the state of equilibrium is set, which dynamically changes, but does not affect the health of poultry. However, microbial associations that accumulate excessively in litter materials of the poultry house pose a threat to bird health and its productivity [14]. Extracts of essential oils from plants have long been known for their antimicrobial activity and is an alternative to antibiotics in the cultivation of broiler chickens both in Ukraine and abroad. In vivo studies on broilers demonstrated antimicrobial efficacy of essential oils against Escherichia coli and Clostridium perfringens. So far, the antimicrobial mechanism of the influence of essential oils has not been clarified. However, it is believed that their lipophilic properties and the chemical structure can play their role.

Essential oils of the laurel, cinnamon, thyme and cloves, as well as oregano, basil, coriander and other plants were tested against the bacteria and fungi present in the feed. Oregano essential oils have a high antimicrobial potential, even against gram-negative bacteria, which are usually very resistant to essential oils from other plants [15].

Thus, without proper environmental control and systematic monitoring of the accumulation of pollutants, litter materials pose a potential threat of poultry contamination with pathogenic and opportunistic microorganisms, and in the process of their use from the litter a significant amount of ammonia and other xenobiotics is released, which negatively affect the preservation, productive parameters of a bird and the transformation of feed, and ventilation emissions of poultry houses - to the natural environment. 


\section{Purpose and tasks of the research}

Purpose - carry out chemical and microbiological analysis of litter, investigate the bactericidal properties of essential oils.

To achieve the purpose, the following tasks were set:

1. Sampling of litter broiler production at the initial and final stages of growing poultry breeding;

2. Chemical and microbiological research of litter with broiler growing of poultry;

3 . Investigation of bactericidal properties of emulsions of essential oils at concentrations of 0.5 and $1 \%$ on the growth of lactose-positive E. coli and conditionally pathogenic bacteria of the genus Proteus.

\section{Materials and methods}

The research was carried out at the enterprises of broiler production in the Kiev region. There were sampled 33 samples of litter by the envelope method in the broiler poultry farm - in the initial (10-15 days) and final (37-43 days) period of poultry breeding.

The chemical composition and microbiological studies of litter were carried out in the «Ukrainian laboratory of quality and safety of agricultural products» of the National university of life and environmental sciences of Ukraine and the microbiological laboratory of the Department of Ecology Ltd. "Complex Agromars" according to DSTU ISO 11885:2005 and DSTU 30726-2002.
Appropriate techniques have allowed to investigate the litter for the presence of microorganisms of the genus Salmonella, lactose-positive E. coli and opportunistic bacteria of the genus Proteus, total microbial number and the humidity of the litter.

For studying bactericidal properties of essential oils according to DSTU 50474-93, we prepared agaric selective diagnostic medium (MPB) $5 \mathrm{ml}$ per test tube, added 1 $\%$ solution of essential oil emulsion, made in a Petri dish, after which added sown in advance culture of $E$. coli and Proteus. Strains of the studied microorganisms were provided by the microbiological laboratory of the Department of Ecology Ltd. "Complex Agromars". The emulsion of essential oil was obtained by dissolving it in an organic solvent namely in ethyl alcohol. Essential oils were purchased at a private firm "Leko Style" with an appropriate passport for each. Control was provided by nutrient media with microorganisms, which contained $0,05 \mathrm{ml}$ of distilled water. Thermostated at $37^{\circ} \mathrm{C} 2$ days, after which a visual review of the growth of microorganism colonies was conducted.

\section{Results of research and their discussion}

At the initial stage of growing poultry it was found that in the samples of litter, the moisture content was $22,1 \%$, and the amount of dry matter was $77,9 \%$ (Table 1).

The general composition of the litter with broiler production from cultivation period of 10-15 days

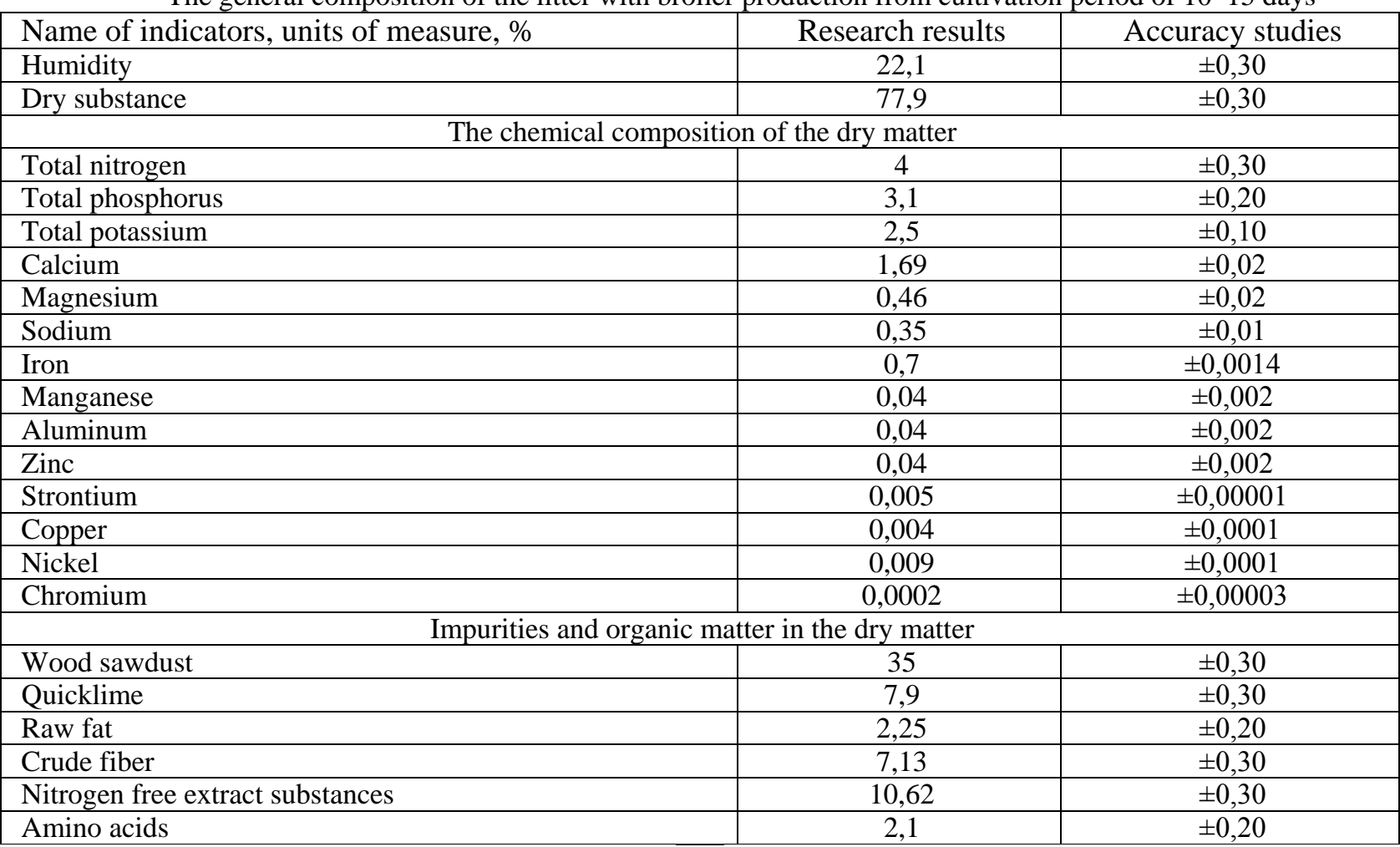

The data, presented in the table, show that in the initial stage of growing poultry there is the presence of such chemical elements in the dry matter of the litter $-\mathrm{N}, \mathrm{P}, \mathrm{K}$, $\mathrm{Ca}, \mathrm{Mg}, \mathrm{Na}, \mathrm{Fe}, \mathrm{Mn}, \mathrm{Al}, \mathrm{Zn}, \mathrm{Sr}, \mathrm{Cu}, \mathrm{Ni}, \mathrm{Cr}$, impurities (wood sawdust and quicklime) and organic matter. The titer of coliform bacteria is absent, the presence of pathogenic microorganisms, including bacteria of the genus Salmonella, was not detected, which indicates a satisfactory sanitary state of poultry breeding enterprises.
Since at the final stage of growing poultry, the humidity of the litter increases, accordingly it accumulates more microorganisms, consequently, microbiological studies of litter are more appropriate. In the study of three variants of litter (37, 40 and 43 days of growing poultry) we took into account the moisture of the litter, total microbial number and the presence of microorganisms of the genus Salmonella and lactopose-positive $E$. coli (Table 2). 
Table 2

Results of microbiological analysis of litter

\begin{tabular}{|c|c|c|c|c|}
\hline Variants & Humidity, in \% & $\begin{array}{c}\text { TMN } \\
\text { CFU/g dry matter }\end{array}$ & $\begin{array}{c}\text { Coli index } \\
\text { CFU/g dry matter }\end{array}$ & Salmonella \\
\hline 37 days of growing poultry & 51,52 & $1,27 \cdot 10^{9} \pm 0,2$ & $1,6 \cdot 10^{6}$ & Absent \\
\hline 40 days of growing poultry & 53,45 & $1,74 \cdot 10^{8} \pm 0,11$ & Absent & Absent \\
\hline 43 days of growing poultry & 56,25 & $3,39 \cdot 10^{8} \pm 0,35$ & Absent & Absent \\
\hline
\end{tabular}

The above results indicate that the TMN in the first variant of the litter is the smallest of $1,27 \cdot 10^{9} \mathrm{CFU} / \mathrm{g}$ dry matter. The presence of lactose-positive intestinal sticks in $1 \mathrm{~g}$ of litter is less than 3 , which indicates its proper sanitary condition, while in the other two variants it is absent at all. The evidence of quality production of broiler production is the absence of a pathogenic microorganism of the genus Salmonella in our studies.

According to [16], bacteria of the genus Salmonella are a causative agent of salmonellosis - the main foodborne disease that the poultry industry faces in the whole world. In total, there are over 2400 serotypes of this microorganism. The most dangerous species for humans is $S$. typhimurium and $S$. enteritidis. In broiler production, $S$. enteritidis is the most common causative agent of food poisoning (33.9\% of cases). In 2015 there were about 95 thousand cases of salmonellosis among people. Foods and water are contaminated through the litter and are the main cause of the spread of the disease in poultry.

$S$. typhimurium, rarely $S$. enteritidis, which are very common in nature, often inhabit the gastrointestinal tract of a healthy bird. Salmonella - small mobile gramnegative sticks, spores and capsules do not form. Salmo- nella is resistant to environmental factors: they are kept in poultry litter for more than 3 months, in the land more than a year, in the corpses buried in the ground - in the summer for 25-40 days, in the winter for 21-31 days in standing water-up to 7 months. They are inactivated at $60^{\circ} \mathrm{C}$ in 30 minutes, at boiling - after $1 \mathrm{~min}$, under the action of direct sunlight - in 5-9 hours [17].

Actuality of the problem of neutralization of pathogenic and conditionally pathogenic organisms developing in litter in conditions of broiler production is associated with a stable increase in the resistance of key microorganisms to traditional antibacterial agents [18]. One of the promising antibacterial preparations with a wide spectrum of action is essential oils of plants [19].

For the study of bactericidal properties of essential oils, 9 samples of essential oils of such plants were tested: Basil (Ocimum basilicum), Coriander (Coriandrum sativum), Mint pepper (Méntha piperita), Garlic (Allium sativum), Laurel (Laurus nobilis), Cinnamon (Cinnamomum verum), Carnation (Syzygium aromaticum), Lime (Citrus aurantiifolia) and Thyme (Thymus) with a concentration of $1 \%$ and $0,5 \%$ of essential oil solution (Table 3).

Table 3

Bactericidal properties of essential oils

\begin{tabular}{|l|c|c|c|}
\hline Name essential oil & $\begin{array}{c}\text { E. coli } 1 \% \text { solution } \\
(0,05 \mathrm{ml} \mathrm{EO} * \\
5 \mathrm{ml} \mathrm{MPB} * *)\end{array}$ & $\begin{array}{c}\text { Proteus vulgaris } 1 \% \text { solution } \\
(0,05 \mathrm{ml} \mathrm{EO} / 5 \mathrm{ml} \mathrm{MPB})\end{array}$ & $\begin{array}{c}\text { Proteus vulgaris 0,5 \% solu- } \\
\text { tion }(0,05 \mathrm{ml} \text { EO/ 10 ml dis- } \\
\text { tilled water / 5 ml MPB })\end{array}$ \\
\hline Ocimum basilicum & + & + & - \\
\hline Coriandrum sativum & + & + & + \\
\hline Méntha piperita & + & + & Not investigated \\
\hline Allium sativum & - & + & - \\
\hline Laurus nobilis & + & + & + \\
\hline Cinnamomum verum & + & + & Not investigated \\
\hline Syzygium aromaticum & - & + & + \\
\hline Citrus aurantiifolia & + & + & - \\
\hline Thymus & + & + & \\
\hline
\end{tabular}

Thus, 7 out of 9 essential oils have bactericidal properties at a minimum concentration of $0.05 \mathrm{ml} / 5 \mathrm{ml}$ of MPB ( $1 \%$ concentration of solution). When the volume of the solution increases due to distilled water, the growth of the culture is not suppressed and essential oils lose their bactericidal properties. Therefore, in the future it will be relevant to study the preparation of the drug with a concentration of essential oils to $1 \%$ to determine the optimal-minimum dose for decontamination of the litter from pathogenic microbiota.

\section{Conclusions}

1. Chemical and microbiological analysis of litter has been carried out at the initial and final stages of broiler production, as a result of which it has been shown that in addition to chemical elements and impurities, in the dry matter of the litter there is also an organic matter in the form of raw fat, crude fiber, nitrogen free extract substances and amino acids.

2. It has been shown that there are no pathogenic microorganisms of the genus Salmonella in poultry broiler samples, this testifies to the high quality of products and the satisfactory epidemiological and sanitary state of the investigated poultry enterprise.

3. There are estimated bactericidal properties of essential oils on lactose-positive bacteria E. coli and conditionally pathogenic bacteria $P$. vulgaris. At a minimum concentration of $0.05 \mathrm{ml} / 5 \mathrm{ml}$ of agarized diagnosticselective medium, 7 of 9 suspensions of essential oils had bactericidal action. 
References

1. Gerber P., Opioand C., Steinfeld H. Poultry production and the environment - a review: Proceedings // Poultry in the 21 st Century: avian influenza and beyond. Bangkok, 2008. Issue 9. P. 379-405.

2. Nahm K. H. A strategy to solve environmental concerns caused by poultry production // World's Poultry Science Journal. 2000. Vol. 56, Issue 4. P. 379-388. doi: http://doi.org/10.1079/wps20000026

3. Ekolohichna otsinka stanu dovkillia v zonakh vyrobnytstva produktsii ptakhivnytstva / Borodai V. P. et. al. // Suchasne ptakhivnytstvo. 2014. Issue 4 (137). P. 22-25.

4. Vykorystannia mikrobiolohichnykh pokaznykiv dlia otsinky gruntu, stichnoi vody ta vidkhodiv ptakhivnychoho kompleksu / Tertychna O. V. et. al. // Silskohospodarska mikrobiolohiia. Chernihiv, 2009. P. 147-149.

5. Sposib oderzhannia orhano-mineralnoho dobryva: Pat. No. 108158 UA. MPK C05F3/00, C05F15/00, C05G1/00 / Mineralov O. I. et. al. No. u 2015 11949; declared: 03.12.2015; published: 11.07.2016. Bul. No. 13.

6. Isman M. B., Machial C. M. Pesticides based on plant essential oils: From traditional practice to commercialization // Naturally Occurring Bioactive Compounds. 2006. Vol. 5. P. 29-44. doi: http://doi.org/10.1016/s1572-557x(06)03002-9

7. Melnyk O. V. Sposoby obrobky pidstylky ptashnykiv // Mizhvidomchyi naukovyi tematychnyi zbirnyk "Ptakhivnytstvo". 2010. Issue 65. URL: http://avianua.com/archiv/ptahivnictvo/65/3.pdf

8. Veterynarno-sanitarni pravyla dlia ptakhivnytskykh hospodarstv ta vymohy do yikh proektuvannia: Zatverdzheni nakazom Holovnoho derzhavnoho inspektora veterynarnoi medytsyny Ukrainy 23.07.2001 No. 53, zareiestrovani Ministerstvom yustytsii Ukrainy 05.07.2001 za No. 565/5756.

9. Zoohyhyena s osnovamy proektyrovanyia zhyvotnovodcheskykh obektov / Naydenskiy M. S. et. al. Moscow: Kolos, 2007. 389 p.

10. Pidpryiemstva ptakhivnytstva: Vidomchi normy tekhnolohichnoho proektuvannia VNTP - APK - 04.05. Kyiv: Minahropolityky Ukrainy, 2005. $92 \mathrm{p}$.

11. Melnyk V. O. Ekolohichni problemy suchasnoho ptakhivnytstva // Ptakhivnytstvo. 2009. Issue 63. P. 3-17.

12. Nahm K. H. Factors influencing nitrogen mineralization during poultry litter composting and calculations for available nitrogen // World's Poultry Science Journal. 2005. Vol. 61, Issue 2. P. 238-255. doi: http://doi.org/10.1079/wps200455

13. Zon H. A. Rezultaty bakteriolohichnoho skryninhu obiektiv ptakhofabryky ta produktsii ptakhivnytstva ta kormiv // Annals of Mechnicov's Institute. 2005. Issue 3. P. 13-17.

14. Kucheruk M. D., Zasiekin D. A. Shchodo mikrobnoho zabrudnennia povitrianoho seredovyshcha ptashnykiv // Suchasni problemy hihiieny, ta sanitarii u tvarynnytstvi. 2011. Issue 8 (48). P. 1-3.

15. Hunchak A. V., Hunchak V. M., Ratych I. B. Biolohichnyi efekt roslynnykh ekstraktiv v orhanizmi ptytsi // Scientific Messenger of Lviv National University of Veterinary Medicine and Biotechnologies named after S. Z. Gzhytsky. 2015. Vol. 17, Issue 13 (63). P. 19-31. salmoneli

16. Kontrol salmonel // Nashe ptakhivnytstvo. 2018. Issue 2. URL: http://www.agrotimes.net/journals/article/kontrol-

17. Epizootolohiia z mikrobiolohiieiu / Kozlovska H. V. et. al.; ed. by Postoi V. P. Kyiv: Vyshcha osvita, 2006. 543 p.

18. Fotina H. A., Klishchova Zh. Ye. Chutlyvist zbudnykiv bakterialnykh khvorob ptytsi do antybakterialnykh preparativ // Scientific Messenger of Lviv National University of Veterinary Medicine and Biotechnologies named after S.Z. Gzhytsky. 2016. Vol. 18, Issue 3 (71). P. 182-185.

19. Essential Oils of Aromatic Plants with Antibacterial, Antifungal, Antiviral, and Cytotoxic Properties - an Overview / Reichling J. et. al. // Complementary Medicine Research. 2009. Vol. 16, Issue 2. P. 79-90. doi: http://doi.org/10.1159/000207196

Дата надходження рукопису 15.05.2018

Olha Tertychna, Doctor of Biological Sciences, Senior Researcher, Department of Ecotoxicology, Laboratory Soil Rehabilitation, Institute of Agroecology and Environmental Management of The National Academy of Agrarian Sciences of Ukraine, Metrolohichna str., 12, Kyiv, Ukraine, 03143,

E-mail: olyater@ukr.net

Svaliavchuk Larysa, Postgraduate Student, Department of Ecotoxicology, Laboratory Monitoring of Agricultural Biological Resources, Institute of Agroecology and Environmental Management of The National Academy of Agrarian Sciences of Ukraine, Metrolohichna str., 12, Kyiv, Ukraine, 03143

E-mail: svaliavchuklarisa@ukr.net

Mineralov Oleg, Researcher, Department of Ecotoxicology, Laboratory Monitoring of Agricultural Biological Resources, Institute of Agroecology and Environmental Management of The National Academy of Agrarian Sciences of Ukraine, Metrolohichna str., 12, Kyiv, Ukraine, 03143,

E-mail: mineralovo@gmail.com 